\title{
Blackberry and Raspberry Cultivar Evaluations in Coastal California
}

\author{
Oleg Daugovish ${ }^{1}$, Mark Gaskell ${ }^{1}$, Miguel Ahumada ${ }^{2}$, and \\ Anna D. Howell ${ }^{3}$
}

ADDITIONAL INDEX WORDS. cane management, fruit shelf life, primocane caneberries

SUMMARY. Increased productivity of recently developed primocane raspberry (Rubus idaeus) and blackberry ( $R$ ubus sp.) cultivars have been accompanied by dramatic improvements in fruit firmness, shape, size, color, and flavor. These traits have contributed to the establishment of these crops throughout California. In this study, we evaluated publically available raspberry and blackberry cultivars for fruit yields, postharvest quality, and production in response to pruning management, at two locations in the central coast of California. Among raspberries, 'Imara' and 'Kweli' were the highest yielding cultivars at both trial locations while 'Kwanza' produced $30 \%$ to $50 \%$ larger fruit, by weight, with postharvest shelf life superior to that of 'Vintage'. Among blackberries, 'Prime-Ark ${ }^{\circledR} 45$ ' was the top-yielding cultivar and had the largest fruit at both locations during both years. 'Prime-Ark ${ }^{\circledR}$ 45' and 'Prime-Ark ${ }^{\circledR}$ Traveler' had comparable weights after 13 days in cold storage in 2018, while in 2019 'Prime-Ark ${ }^{\circledR} 45$ ' and 'APF 268T' had comparable fruit weight. Greater and earlier fruit yields of both blackberries and raspberries were obtained with combined production from floricanes and primocanes compared with primocane production alone. However, increase in cane density in combined production can complicate management of pests, fertigation, and fruit harvest efficiency. With increased interest in primocane cultivars, the information generated in this study has provided new resources to guide successful production by small, independent, and direct-sale growers.

$\mathrm{C}$ onsumer interest in raspberries (Rubus idaeus) and blackberries (Rubus sp.), members of caneberry group (Rubus), has been increasing in recent years because of their health benefits and the organoleptic quality (Lawless, 2012; Nile and Park, 2014). These caneberries have rapidly become important contributors to coastal California agricultural economies.

Received for publication 9 Mar. 2021. Accepted for publication 8 June 2021.

Published online 15 July 2021.

${ }^{1}$ University of California, Agriculture and Natural Resources, 669 County Square Drive \#100, Ventura, CA 93003 and 2156 Sierra Way \#C, San Luis Obispo, CA 93401

${ }^{2}$ Turnford Berry World, Great Cambridge Road, Broxbourne, UK EN106NH

${ }^{3}$ Gowan Company, 370 S Main Street, Yuma, AZ 85364

We would like to acknowledge support from the University of California Thelma Hansen grant program and from the Nourse Farms. We greatly appreciate assistance of the University of California Agriculture and Natural Resources volunteers and Master Gardeners in collecting data.

O.D. is the corresponding author. E-mail: odaugovish@ucanr.edu.

This is an open access article distributed under the CC BY-NC-ND license (https://creativecommons. org/licenses/by-nc-nd/4.0/).

https://doi.org/10.21273/HORTTECH04843-21
For example, in Ventura County, CA, the annual value of caneberries is over \$200 million according to the Ventura County Agricultural Commissioner's Crop and Livestock Report (Ventura County, 2019).

Raspberries and blackberries are typically grown in relatively shortterm cycle in California compared with traditional caneberry production (Bolda et al., 2012). Primocane raspberries are often planted at high density to rapidly fill a hedgerow, then removed and replanted to new plants in 24- to 30-month cycles. Although primocane blackberries often remain for several years in the same spot with individual plant separation, they are often cutback to the soil surface periodically to control timing of production, plant architecture, and manage redberry mite (Acalitus essigi) infestations (Gaskell et al., 2015). These planting systems predominate in mild coastal production sites where longseason production is desirable.

California caneberry growers can produce as part of large commercial marketing companies that make their proprietary cultivars available only to their growers or they can choose to grow and market fruit independently using publicly available cultivars. There is relatively limited planted area $(<20 \%$ of the total $)$ devoted to publicly available cultivars compared with those developed by proprietary fruit marketing companies with their own breeding programs (M. Bolda, personal communication). Raspberry and blackberry breeding programs by public institutions in the United States are limited and many new cultivars come from European sources and other programs outside of the United States. The U.S. Department of Agriculture (USDA) regulates importation and release of new cultivars that are vegetatively propagated (Jenderek et al., 2007), and this often involves a 2 -year quarantine period during which distribution of plant materials is limited. Thus, new, publicly available cultivars can be slow to become available to U.S. berry growers.

Several new blackberry cultivars have been evaluated in California in the last few years (Tourte et al., 2016), but Prime-Ark ${ }^{\circledR}$ 45-a newer primocane-fruiting blackberry released by the University of Arkansas in 2011-has been widely planted at coastal California sites for several years. Primocane-fruiting cultivars with commercial quality characteris-

\begin{tabular}{llll}
\hline $\begin{array}{l}\text { Units } \\
\text { To convert U.S. to SI, } \\
\text { multiply by }\end{array}$ & U.S. unit & SI unit & $\begin{array}{l}\text { To convert SI to U.S., } \\
\text { multiply by }\end{array}$ \\
\hline 1 & $\mathrm{cbar}$ & $\mathrm{kPa}$ & 1 \\
0.3048 & $\mathrm{ft}$ & $\mathrm{m}$ & 3.2808 \\
3.7854 & gal & $\mathrm{L}$ & 0.2642 \\
2.54 & inch $(\mathrm{es})$ & $\mathrm{cm}$ & 0.3937 \\
1.1209 & $\mathrm{lb} / \mathrm{acr}$ & $\mathrm{kg} \cdot \mathrm{ha}^{-1}$ & 0.8922 \\
0.0254 & $\mathrm{mil}(\mathrm{s})$ & $\mathrm{mm}$ & 39.3701 \\
28.3495 & $\mathrm{Oz}$ & $\mathrm{g}$ & 0.0353 \\
93.0102 & $\mathrm{oz} / \mathrm{ft}$ & $\mathrm{g} \cdot \mathrm{m}^{-1}$ & 0.0108 \\
1 & $\mathrm{ppm}$ & $\mathrm{mg} \cdot \mathrm{kg}^{-1}$ & 1 \\
$\left({ }^{\circ} \mathrm{F}-32\right) \div 1.8$ & ${ }^{\circ} \mathrm{F}$ & ${ }^{\circ} \mathrm{C}$ & $\left({ }^{\circ} \mathrm{C} \times 1.8\right)+32$ \\
& & &
\end{tabular}


tics and postharvest potential for shipping provide opportunities for current and prospective growers to produce marketable fruit during extended seasons and production areas (Clark and Perkins-Veazie, 2011). California growers predominantly use primocanebearing cultivars in high tunnel culture $(\approx 80 \%$ of the acreage $)$ for an extended production season (Gaskell et al., 2015; Tourte et al., 2016).

To address the needs of small- and medium-sized independent growers, we evaluated recently released publicly available cultivars of raspberries and blackberries in two coastal California locations representing different production environments within the same production region. The objective of the project was to assess their fruit production and quality under different management regimes to provide the basis for developing recommendations for independent growers.

\section{Materials and methods}

During 2017-19, we evaluated the performance of five primocane-fruiting raspberry and four primocane-fruiting blackberry public cultivars at two coastal California locations: Santa Paula [Ventura County (lat. $34^{\circ} 2 \mathrm{I}^{\prime} 15.0 \mathrm{I}^{\prime} \mathrm{N}$, long. $\left.119^{\circ} 03^{\prime} 33.37^{\prime} \mathrm{W}\right)$ ] and Oceano [San Luis Obispo County (lat. $35^{\circ} 05^{\prime} 55$. $90^{\prime} \mathrm{N}$, long. $\left.\left.120^{\circ} 36^{\prime} 44.60^{\prime} \mathrm{W}\right)\right]$.

The Santa Paula site soil was fineloamy, mixed, superactive, thermic Pachic Haploxerolls (75\% clay, 25\% silt) soil with $\mathrm{pH}$ of 7.6 and $1.2 \%$ organic matter (University of California, Davis, 2021). The soil was flat fumigated in June 2016 via shank injection of $300 \mathrm{lb} /$ acre of chloropicrin (Trinity Manufacturing, Hamlet, NC) and covered with totally impermeable film (AGRO-TIF, no pigment/natural clear, 1-mil-thick; USA Extruded Plastics, Anaheim, CA). Fumigation plastic was removed in July and soil was sprinkler irrigated. Twelve beds $(130 \mathrm{ft}$ long, $3 \mathrm{ft}$ wide, $\mathrm{l} \mathrm{ft}$ tall) were shaped and a single low-flow irrigation drip lines (John Deere, Moline, IL, or Aqua-Traxx; Toro Ag, Rome, Italy) were placed in the centers of all beds. These drip lines were delivering about $4 \mathrm{~L} \cdot \mathrm{min}^{-1}$ per $100 \mathrm{~m}$. Four high tunnels ( $9 \mathrm{~m}$ wide, with $\mathrm{l}-\mathrm{m}$-tall sides and 6-m-tall arch) were installed to encompass three beds each. The tunnel arches were covered with 6-mil-thick clear plastic mulch (Ginegar Plastic
Products, Kibbutz Ginegar, Israel), secured to the arches with string. Tunnel ends remained opened and tunnel sides remained open $1 \mathrm{~m}$ from the ground. Plastic remained in place throughout the experiment.

Each of the four tunnels was a replicate, containing main plots: three beds assigned one of the three cane management regimes. Within each of the three beds, nine 2.6-m-long subplots were bed sections randomly planted with one of five raspberry or four blackberry cultivars. Four root plugs of each blackberry cultivar or six of each raspberry cultivar were planted in subplots. Plants were spaced in such a way that 3 years of production could be evaluated from individual plants with little interplant competition. Due to a lack of plant material, there were two planting dates. In Sept. 2016, we planted 'Kwanza', 'Kweli', and 'Imara' raspberries and 'PrimeArk ${ }^{\circledR} 45$ ' and 'PrimeArk ${ }^{\circledR}$ Traveler' (thornless) blackberries. In Apr. 2017, we planted 'Vintage' and 'Kokanee' raspberries and 'APF-268T' and 'ORUS 4545-1' blackberries. Plants were fertigated with $7 \mathrm{lb} /$ acre of nitrogen $(\mathrm{N})$ applied as calcium ammonium nitrate $[27 \mathrm{~N}$ 0P-0K (CAN 27; Yara North America, Tampa, FL)] via drip injection biweekly during one of three weekly irrigations. Irrigation maintained soil moisture at 15-cm depth between 10 and 20 cbar.

A V-shaped trellis (Bolda et al., 2012) was installed at planting and remained in place until the completion of the experiment. The trellis consisted of two 2 -m-long metal posts placed $0.5 \mathrm{~m}$ deep into soil forming a $30^{\circ}$ angle every $6 \mathrm{~m}$. Cord lines connected all posts (and were replaced as needed) at $0.5,1$, and $1.5 \mathrm{~m}$ aboveground. Management of weeds and two-spotted spider mites (Tetranychus urticae) followed production and pest management guidelines (Bolda et al., 2012).

Fruit were harvested two to three times per week in all plots, separated into marketable and unmarketable, and weighed. In 2017, we harvested from cultivars without consideration of management regimes, which were introduced in 2018 and maintained in 2019.

Three management regimes of raspberries at Santa Paula were: $1=$ cut all canes in December at $1 \mathrm{~m}$ aboveground (for floricane production next season), maintaining 25 primocanes (emerged in March) per meter of bed during season; 2 = same as regime 1 , but remove floricanes in May; $3=$ mow all canes at ground level in December, maintaining 25 primocanes (emerged in March) per meter of bed during season.

Three management regimes of blackberries were: 1 = cut all canes in December at $1 \mathrm{~m}$ aboveground (for floricane production next season); 2 = cut all canes in December at $1 \mathrm{~m}$ aboveground (for floricane production next season) and in-season pruning $25-50 \mathrm{~cm}$ from cane tops to improve harvest access and branching; $3=$ mow all canes at ground level in December and remove, then single pruning of primocanes in May at 120 $\mathrm{cm}$ from the ground to facilitate branching.

At each harvest, 10 berries were randomly selected from the marketable fruit fraction in each plot, weighed and average fruit weight determined as estimate of fruit size. Additionally, in Sept. 2017 and 2018, we collected marketable fruit for evaluation of postharvest performance in cold storage using a completely randomized design (CRD) experiment with four replications. Plastic "clamshells" (TYPACK; San Bernardo, Santiago, Chile) were filled with $170 \mathrm{~g}$ of fruit of each of the caneberry cultivar and placed on shelves at $3{ }^{\circ} \mathrm{C}$ and $65 \%$ relative humidity within $2 \mathrm{~h}$ from harvest. At $1,3,5,7,9$, and $13 \mathrm{~d}$ after placement, clamshells were weighed to determine weight losses and fruit were observed for presence of decay. In August of each year we collected 12 soil cores $(0-30 \mathrm{~cm})$ per replicate for comprehensive soil analyses at the Fruit Growers Laboratory (FGL, Santa Paula, CA). Analyses included macro- and micronutrient contents, soil salinity, sodium absorption ratio, $\mathrm{pH}$, and soil moisture. Due to poor plant performance of all raspberry cultivars in response to increasing soil salinity, fruit yield and quality data were not recorded for raspberries at Santa Paula during the 2019 season.

At Oceano, the experimental site soil was coarse-loamy over sandy, mixed, thermic Fluventic Haploxerolls $(65 \%$ sand, $14 \%$ silt, and $19 \%$ clay) with $\mathrm{pH} 7.2$ and $1.7 \%$ organic matter. (University of California, Davis, 2021). The trial was situated in the middle of a grower's certified organic caneberry production field and used two polyethylene tunnels of 
a five-tunnel field grouping. The experimental area received locally sourced compost that was incorporated preplant at a rate of $2000 \mathrm{lb} /$ acre. The compost was expected to provide adequate levels of phosphorus $(\mathrm{P})$ and potassium $(\mathrm{K})$. Compost analysis was not available for this specific application, but composts from these commercial facilities are routinely equivalent to $1 \mathrm{~N}-1 \mathrm{P}-1 \mathrm{~K}$ (percent on dry weight basis) and have $25 \%$ to $27 \%$ moisture. This field has been in intensive vegetable and berry production for more than 20 years and routinely tested high for nutrients other than $\mathrm{N}$. The initial compost applications were complemented by in-season injections of $\mathrm{N}$ into the drip system at $5 \mathrm{lb} /$ acre $\mathrm{N}$ per week as $8 \mathrm{~N}-0 \mathrm{P}-0 \mathrm{~K}$ organic fertilizer (N Force; Healthy Soils, Salinas, CA) as part of routine grower management practices.

Tunnels and beds at Oceano were constructed similar to those at Santa Paula, except high-flow drip tape delivering $7.8 \mathrm{~L} \cdot \mathrm{min}^{-1}$ per 100 $\mathrm{m}$ were used in bed centers and beds were covered with plastic (white on top and black on the bottom) to control weeds. Unlike at Santa Paula, transparent plastic on tunnels at Oceano was removed December-March to allow rain-fed leaching of salts accumulated from the prior irrigation season as part of grower management practices typical for that region (Bolda et al., 2012). Pruning management regimes were not evaluated at Oceano but were uniformly the same as the no. 1 treatment regime for raspberries and blackberries at Santa Paula. Other practices were the same as the grower practices in neighboring production tunnels. Marketable fruit yields and fruit sizes were recorded as at Santa Paula; however, no unmarketable fruit data were recorded at Oceano.

Since the treatments differed among sites, the data were analyzed separately for each location/season dataset. Analyses of variance and differences between treatment means were determined using Fisher's least significant difference test $(P>0.05)$. All statistical computations were performed using SAS (version 9.3; SAS Institute, Cary, NC).

\section{Results and discussion}

FRUIT YIELDS AND FRUIT SIZES. At Santa Paula in 2017 raspberries planted in Sept. 2016-'Imara' and 'Kweli' had 83\% greater yield than 'Kwanza' (Table 1). 'Imara' and 'Kweli' produced fruit earlier in the summer than 'Kwanza', which remained vegetative longer than other raspberries planted at the same time (data not shown). In 2018 , raspberry yields were lower than in 2017 and similar among all cultivars. Poor raspberry performance in 2018 at Santa Paula was likely due to accumulation of salts in the root zone where soil sampled in Aug. 2018 at $0-30 \mathrm{~cm}$ depth contained $470 \mathrm{ppm}$ of chloride, which is nearly three times greater than optimal concentration for raspberry (Bolda et al., 2012). Irrigation with single drip tape per bed and lack of rainwater in closed tunnels were inadequate for salt leaching and all raspberry cultivars had marginal leaf necrosis and poor growth commonly associated with salt injury. Prive et al. (1993) identified adequate irrigation as a key component influencing fruit yields of primocane-fruiting raspberries and it became a limiting factor to fruit production at the Santa Paula site. Additionally, soil $\mathrm{pH}$ in root zone ranged from 7.8 to 8.0 , much higher than the recommended range (5.5-6.5), likely limiting availability of several micronutrients to plants. For example, zinc levels in soil sampled in Aug. 2018 at 0-30 $\mathrm{cm}$ depth were 1.5 to $1.8 \mathrm{ppm}$, three to five times lower than recommended range (Bolda et al., 2012).

At Oceano, variations in planting date and initial transplant size created variations in early plant phenology that prevented harvest data collection in 2017. In 2018, all raspberry cultivars yielded similarly except Kwanza, which had 34\% lower marketable fruit yield than Imara and Kokanee but similar to yields of Kweli and Vintage (Table 1). Delayed fruit production

Table 1. Marketable fruit yields of five raspberry and four blackberry cultivars in high tunnels at Santa Paula, CA, and Oceano, CA, in 2017-19.

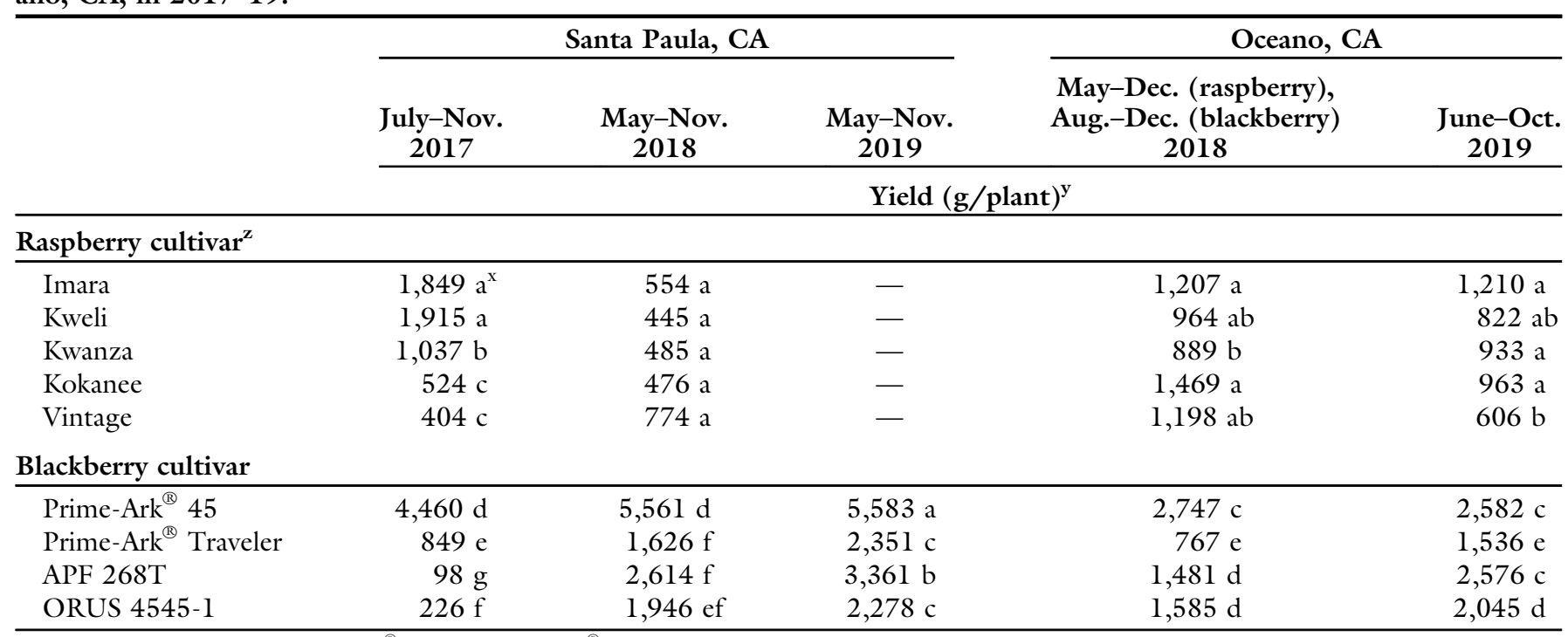

"Kwanza', 'Kweli', 'Imara', 'Prime-Ark ${ }^{\circledR} 45$ ', and 'Prime-Ark ${ }^{\circledR}$ Traveler' were planted in Sept. 2016. 'Vintage', 'Kokanee', 'APF-268T', and 'ORUS 4545-1' were planted in Apr. 2017.

${ }^{\mathrm{y}} 1 \mathrm{~g}=0.0353 \mathrm{oz}$.

${ }^{\mathrm{x}}$ Different letters next to treatment means within each column for raspberries or blackberries indicate significant differences according to Fisher's least significant difference test $(P>0.05)$. 
for 'Kwanza', also observed at Santa Paula, likely contributed to these differences at Oceano as well. 'Kwanza' has been characterized as a late-fruiting cultivar whereas Imara as early fruiting (Advanced Berry Breeding, unpublished data). However, marketable fruit yield of 'Kwanza' in 2019 at Oceano was not different from other raspberry cultivars and $54 \%$ greater than Vintage yield (Table 1 ).

At Santa Paula, 'Prime-Ark ${ }^{\circledR} 45^{\prime}$ was consistently the highest yielding blackberry cultivar in all seasons (Table 1). When evaluated against 'PrimeArk $^{\circledR}$ Traveler', planted at the same date, 'Prime-Ark ${ }^{\circledR} 45$ ' produced 5.2, 3.4 , and 2.4 times more marketable fruit in 2017,2018 , and 2019 , respectively. In 2018 and 2019, when equal comparison among all cultivars became possible due similar cane production and phenology, Prime-Ark ${ }^{\circledR} 45$ produced 2.4 times more marketable fruit than APF $268 \mathrm{~T}$ and ORUS 4545-1 in 2018 and 1.7 times more than APF $268 \mathrm{~T}$ and 2.5 more than ORUS 4545-1 in 2019 (Table 1). Even though blackberries were grown in the same soil conditions and under similar management as raspberries at Santa Paula, plant productivity did not appear to be similarly reduced by increased salinity or micronutrient deficiencies over time in blackberry cultivars. This is likely due to lesser sensitivity of blackberry to salts compared with raspberries (Bolda et al., 2012) and larger root systems in blackberries, capable of using water and nutrients from greater soil volumes compared with raspberries (Hall and Funt, 2017).

At Oceano, yields were not reported for 2017 because of variability among planting dates, transplant sizes, and ages for the different cultivars. Much like at Santa Paula, 'Prime$\mathrm{Ark}^{\circledR} 45$ ' was the highest yielding cultivar in 2018 and 2019 , only similar in yield to APF $268 \mathrm{~T}$ in 2019 (Table 1 ). 'Prime-Ark ${ }^{\circledR}$ Traveler' had lowest marketable yields in both seasons, which were 3.6 and 1.7 times less compared with 'Prime-Ark ${ }^{\circledR} 45$ ' in 2018 and 2019, respectively (Table 1 ).

At Santa Paula, raspberry and blackberry cultivars with greatest marketable yields tended to produce more unmarketable fruit (Table 2). However, unmarketable fruit fraction ranged $23 \%$ to $26 \%$ of total fruit yields in raspberries and $12 \%$ to $17 \%$ in blackberries (Tables 1 and 2). Unmarketable fruit consisted
Table 2. Unmarketable fruit yields of five raspberry and four blackberry cultivars in high tunnels at Santa Paula, CA, in 2017-19.

\begin{tabular}{lccc}
\hline & July-Nov. 2017 & May-Nov. 2018 & May-Nov. 2019 \\
\cline { 2 - 4 } & \multicolumn{3}{c}{ Yield (g/plant) $^{\mathrm{z}}$} \\
\hline Raspberry cultivar & $572 \mathrm{a}^{\mathrm{y}}$ & $107 \mathrm{a}$ & - \\
\hline Imara & $652 \mathrm{a}$ & $111 \mathrm{a}$ & - \\
Kweli & $302 \mathrm{~b}$ & $255 \mathrm{a}$ & - \\
Kwanza & $128 \mathrm{c}$ & $143 \mathrm{a}$ & - \\
Kokanee & $144 \mathrm{c}$ & $277 \mathrm{a}$ & $1,926 \mathrm{a}$ \\
Vintage & & & $953 \mathrm{~b}$ \\
Blackberry cultivar & $913 \mathrm{~d}$ & $774 \mathrm{~d}$ & $1,443 \mathrm{ab}$ \\
\hline Prime-Ark & & \\
Prime-Ark & & & \\
APF 268T & $103 \mathrm{e}$ & $209 \mathrm{e}$ & $1,325 \mathrm{ab}$ \\
\hline ORUS 4545-1 & $31 \mathrm{e}$ & $359 \mathrm{e}$ &
\end{tabular}

${ }^{\mathrm{z}} 1 \mathrm{~g}=0.0353 \mathrm{oz}$.

${ }^{\mathrm{y}}$ Different letters next to treatment means within each column for raspberries or blackberries indicate significant differences according to Fisher's least significant difference test $(P>0.05)$. of fruit with various defects such as discolored or dry drupelets, overripe fruit or berries with symptoms of feeding by larva of spotted wing drosophila (Drosophila suzukii). These fruit were inspected by slicing unmarketable fruit at each harvest (data not shown). Blackberries appeared more durable than raspberry and the presence of a receptacle in harvested blackberry fruit likely decreased number of crumbly fruit that contributed to unmarketable fraction in raspberries, which were harvested without receptacle according to industry standards (Bolda et al., 2012).

At both locations in all seasons, 'Kwanza' produced $30 \%$ to $50 \%$ larger fruit, by weight, than other raspberries (Table 3 ). There were no differences in fruit weights among cultivars other than Kwanza at Santa Paula and at Oceano in 2018, but in 2019 at Oceano Kweli had 19\% heavier fruit than Imara, Kokanee, and Vintage, which were similar (Table 3).

Among blackberries, 'Prime$\operatorname{Ark}^{\circledR} 45^{\prime}$ at both locations and in all seasons had the largest fruit but not significantly different in weight from 'APF 268T' in 2019 (Table 3). Consistently among seasons and locations, 'Prime-Ark ${ }^{\circledR}$ Traveler' and 'ORUS 4545 - 1 ' fruit were $19 \%$ to $27 \%$ lighter than 'PrimeArk45' (Table 3).

MANAGEMENT REgIME EFFECTS ON FRUIT PRODUCTION. In 2018, at Santa Paula, highest raspberry yields for all cultivars were obtained with a
Table 3. Average fruit weights of five raspberry and four blackberry cultivars in high tunnels at Santa Paula, CA, and Oceano, CA, in 2017-19.

\begin{tabular}{|c|c|c|c|c|c|}
\hline & \multicolumn{3}{|c|}{ Santa Paula, CA } & \multicolumn{2}{|c|}{ Oceano, CA } \\
\hline & 2017 & 2018 & 2019 & 2018 & 2019 \\
\hline & \multicolumn{5}{|c|}{$\mathrm{Wt}(\mathrm{g} / \text { fruit })^{\mathrm{z}}$} \\
\hline \multicolumn{6}{|l|}{$\underline{\text { Raspberry cultivar }}$} \\
\hline $\begin{array}{l}\text { Imara } \\
\text { Kweli } \\
\text { Kwanza } \\
\text { Kokanee } \\
\text { Vintage }\end{array}$ & $\begin{array}{l}3.7 \mathrm{~b}^{\mathrm{y}} \\
3.8 \mathrm{~b} \\
5.3 \mathrm{a} \\
3.4 \mathrm{~b} \\
3.4 \mathrm{~b}\end{array}$ & $\begin{array}{l}2.9 \mathrm{~b} \\
3.2 \mathrm{~b} \\
3.9 \mathrm{a} \\
3.0 \mathrm{~b} \\
3.0 \mathrm{~b}\end{array}$ & $\begin{array}{l}- \\
- \\
-\end{array}$ & $\begin{array}{l}3.3 \mathrm{~b} \\
3.5 \mathrm{~b} \\
4.4 \mathrm{a} \\
3.5 \mathrm{~b} \\
3.3 \mathrm{~b}\end{array}$ & $\begin{array}{l}3.6 \mathrm{c} \\
4.2 \mathrm{~b} \\
5.2 \mathrm{a} \\
3.7 \mathrm{c} \\
3.3 \mathrm{c}\end{array}$ \\
\hline \multicolumn{6}{|l|}{ Blackberry cultivar } \\
\hline $\begin{array}{l}\text { Prime-Ark }^{\circledR} 45 \\
\text { Prime-Ark }{ }^{\circledR} \text { Traveler } \\
\text { APF 268T } \\
\text { ORUS 4545-1 }\end{array}$ & $\begin{array}{l}8.4 \mathrm{c} \\
5.6 \mathrm{e} \\
7.0 \mathrm{~d} \\
5.2 \mathrm{e}\end{array}$ & $\begin{array}{l}7.8 \mathrm{c} \\
5.7 \mathrm{e} \\
7.0 \mathrm{~d} \\
5.7 \mathrm{e}\end{array}$ & $\begin{array}{l}8.4 \mathrm{a} \\
6.2 \mathrm{~b} \\
7.9 \mathrm{a} \\
6.6 \mathrm{~b}\end{array}$ & $\begin{array}{l}8.0 \mathrm{c} \\
6.0 \mathrm{~d} \\
6.4 \mathrm{~d} \\
6.1 \mathrm{~d}\end{array}$ & $\begin{array}{l}7.9 \mathrm{~d} \\
6.7 \mathrm{e} \\
7.6 \mathrm{~d} \\
6.1 \mathrm{e}\end{array}$ \\
\hline
\end{tabular}


Table 4. Marketable fruit yields (May-November) in response to three management regimes of five raspberry and four blackberry cultivars in high tunnels at Santa Paula, CA, in 2018-19.

\begin{tabular}{|c|c|c|c|c|c|c|}
\hline & \multicolumn{6}{|c|}{ Management regimes $^{\mathrm{zy}}$} \\
\hline & \multicolumn{3}{|c|}{2018} & \multicolumn{3}{|c|}{2019} \\
\hline & 1 & 2 & 3 & 1 & 2 & 3 \\
\hline & \multicolumn{6}{|c|}{ Yield $\left(\mathrm{g} \cdot \mathrm{m}^{-1} \text { bed }\right)^{\mathrm{x}}$} \\
\hline \multicolumn{7}{|l|}{ Raspberry cultivar } \\
\hline $\begin{array}{l}\text { Imara } \\
\text { Kweli } \\
\text { Kwanza } \\
\text { Kokanee } \\
\text { Vintage }\end{array}$ & $\begin{array}{l}1,917 \mathrm{a}^{\mathrm{w}} \\
2,046 \mathrm{a} \\
1,858 \mathrm{a} \\
1,802 \mathrm{a} \\
1,334 \mathrm{a}\end{array}$ & $\begin{array}{r}1,010 \mathrm{~b} \\
710 \mathrm{~b} \\
898 \mathrm{~b} \\
869 \mathrm{~b} \\
965 \mathrm{~b}\end{array}$ & $\begin{array}{r}1,062 \mathrm{~b} \\
409 \mathrm{~b} \\
741 \mathrm{~b} \\
764 \mathrm{~b} \\
305 \mathrm{~b}\end{array}$ & $\begin{array}{l}- \\
- \\
-\end{array}$ & $\begin{array}{l}- \\
- \\
-\end{array}$ & $\begin{array}{l}- \\
- \\
-\end{array}$ \\
\hline \multicolumn{7}{|l|}{ Blackberry cultivar } \\
\hline $\begin{array}{l}\text { Prime-Ark }{ }^{\circledR} 45 \\
\text { Prime-Ark }{ }^{\circledR} \text { Traveler } \\
\text { APF 268T }\end{array}$ & $\begin{array}{r}10,533 \mathrm{c} \\
3,503 \mathrm{c} \\
5,749 \mathrm{c}\end{array}$ & $\begin{array}{r}10,738 \mathrm{c} \\
2,452 \mathrm{c} \\
2,837 \mathrm{~d}\end{array}$ & $\begin{array}{l}5,502 \mathrm{~d} \\
1,846 \mathrm{~d} \\
3,977 \mathrm{~d}\end{array}$ & $\begin{array}{l}9,802 \mathrm{c} \\
4,707 \mathrm{c} \\
6,363 \mathrm{c}\end{array}$ & $\begin{array}{l}9,819 \mathrm{c} \\
3,915 \mathrm{c} \\
5,744 \mathrm{c}\end{array}$ & $\begin{array}{l}7,177 \mathrm{~d} \\
2,663 \mathrm{~d} \\
4,026 \mathrm{~d}\end{array}$ \\
\hline $\begin{array}{l}{ }^{2} \text { Regimes for management of } \\
\text { cane production next season) } \\
2=\text { same as regime } 1 \text {, but rem } \\
\text { maintain } 25 \text { primocanes (emer } \\
\text { 'Regimes for management of } \\
\text { production next season); } 2= \\
\text { season) and in-season pruning } \\
\text { mow all canes at ground lev } \\
\text { inches) from the ground to en } \\
{ }^{{ }^{y}} 1 \mathrm{~g} \cdot \mathrm{m}^{-1}=0.0108 \mathrm{oz} / \mathrm{ft} \text {. } \\
{ }^{\mathrm{w}} \text { Different letters next to trea }\end{array}$ & $\begin{array}{l}\text { spberries: } 1=\mathrm{cu} \\
\text { dd maintain } 25 \mathrm{f} \\
\text { ve floricanes in } \\
\text { ed in March) pe } \\
\text { lackberries: } 1= \\
\text { tt all canes in D } \\
25-50 \mathrm{~cm}(9.8 \\
\text { in December, } \\
\text { ourage branchin }\end{array}$ & $\begin{array}{l}\text { it all canes in } \mathrm{I} \\
\text { primocanes (en } \\
\text { May; } 3=\text { mow } \\
\text { r } 1 \mathrm{~m} \text { of bed d } \\
\text { cut all canes ir } \\
\text { December at } 1 \\
\text { - } 19.7 \text { inches) } \\
\text { then single pr } \\
\text { g. }\end{array}$ & $\begin{array}{l}\text { ecember at } \\
\text { nerged in Ma } \\
\text { all canes at } \\
\text { luring season } \\
\text { December } \\
\mathrm{m} \text { above gre } \\
\text { from cane to } \\
\text { uning of pri }\end{array}$ & $\begin{array}{l}1 \mathrm{~m}(3.3 \mathrm{ft}) \\
\text { arch) per l } \\
\text { ground level } \\
\text { a. } \\
\text { at } 1 \mathrm{~m} \text { abov } \\
\text { ound (for flo } \\
\text { ops to impr } \\
\text { imocanes in } \\
\text { s or blackbe }\end{array}$ & $\begin{array}{l}\text { abovegroun } \\
\mathrm{m} \text { of bed dur } \\
\text { in Decemb } \\
\text { e ground (f } \\
\text { oricane prod } \\
\text { ove harvest } \\
\text { May at } 120\end{array}$ & $\begin{array}{l}\mathrm{d} \text { (for flori- } \\
\text { ring season; } \\
\text { er and then } \\
\text { or floricane } \\
\text { uction next } \\
\text { access; } 3= \\
\text { cm }(47.2\end{array}$ \\
\hline
\end{tabular}

combination of floricane and primocane production [regime 1 (Table 4$)$ ]. Fruit production began 4 to 6 weeks later in the season in primocanes (regime 3) compared with floricanes,

and primocane-only fruit production was $55 \%$ to $80 \%$ lower. Management regime 2 , in which floricanes were removed to increase spacing and biomass from previous season, resulted in raspberry yields similar to those with primocanes alone [regime 3 (Table $4)$ ]. Fruit harvested from primocanes (regime 3) tended to be larger at some harvests but on average over all harvest dates, not significantly different from fruit harvested from floricanes (data not shown). Removal of all canes and crop biomass between production seasons (primocane-only production) can prevent persistence of overwintering pests such as broad mite (Polyphagotarsonemus latus) and redberry mite, and facilitate access to new canes for management and harvest in the following season (Gaskell et al., 2015). We did not observe differential pest presence in plots with raspberry management regimes, but increased cane density in floricane + primocane plots, while advantageous to fruit production, made access to fruit more difficult and slowed the speed of harvest $(\mathrm{H}$. Lee, personal communication).

In both seasons at Santa Paula, blackberry yields for all cultivars were $27 \%$ to $52 \%$ lower from primocaneonly production (regime 3 ) compared with combinations of floricane and primocane production with two exceptions (Table 3). 'APF 268T' yield in 2018 in primocane-only production (regime 3 ) was similar to floricane production with selective cane pruning (regime 2), while 'ORUS 4545 -1' yield in 2019 in primocane-

Table 5. Weights of raspberry and blackberry fruit placed in cold storage for $13 \mathrm{~d}$ after harvest from high tunnels at Santa Paula, CA, in 2018-19.

\begin{tabular}{|c|c|c|c|c|c|c|c|c|c|c|c|}
\hline \multicolumn{6}{|c|}{2017} & \multicolumn{6}{|c|}{2018} \\
\hline \multicolumn{12}{|c|}{ Time in storage $(\mathrm{d})$} \\
\hline 1 & 3 & 5 & 7 & 9 & 13 & 1 & 3 & 5 & 7 & 9 & 13 \\
\hline
\end{tabular}

\begin{tabular}{lcccccccccccc}
\hline Raspberry cultivar & 167 & 164 & $159 \mathrm{a}^{\mathrm{y}}$ & $157 \mathrm{a}$ & $154 \mathrm{ab}$ & $150 \mathrm{a}$ & 169 & $166 \mathrm{a}$ & $163 \mathrm{a}$ & $162 \mathrm{ab}$ & $157 \mathrm{~b}$ & $150 \mathrm{ab}$ \\
\hline Imara & 166 & 164 & $160 \mathrm{a}$ & $158 \mathrm{a}$ & $156 \mathrm{a}$ & $151 \mathrm{a}$ & 169 & $165 \mathrm{a}$ & $163 \mathrm{a}$ & $161 \mathrm{ab}$ & $158 \mathrm{~b}$ & $151 \mathrm{a}$ \\
Kweli & 168 & 164 & $161 \mathrm{a}$ & $158 \mathrm{a}$ & $156 \mathrm{a}$ & $152 \mathrm{a}$ & 170 & $167 \mathrm{a}$ & $163 \mathrm{a}$ & $163 \mathrm{a}$ & $157 \mathrm{~b}$ & $152 \mathrm{a}$ \\
Kwanza & - & - & - & - & - & - & 169 & $167 \mathrm{a}$ & $165 \mathrm{a}$ & $164 \mathrm{a}$ & $162 \mathrm{a}$ & $152 \mathrm{a}$ \\
Kokanee & 167 & 163 & $157 \mathrm{~b}$ & $155 \mathrm{~b}$ & $153 \mathrm{~b}$ & $143 \mathrm{~b}$ & 168 & $164 \mathrm{~b}$ & $161 \mathrm{~b}$ & $160 \mathrm{~b}$ & $156 \mathrm{~b}$ & $148 \mathrm{~b}$ \\
Vintage & $\mathrm{NS}$ & $\mathrm{NS}$ & & & & & NS & & &
\end{tabular}

Blackberry cultivar

2018

2019

$\begin{array}{lcccccccccccc}\text { PrimeArk }^{\circledR} 45 & 170 & 168 & 166 & 165 & 163 \mathrm{a} & 157 \mathrm{a} & 170 & 169 & 167 \mathrm{a} & 164 \mathrm{a} & 161 \mathrm{a} & 158 \mathrm{a} \\ \text { PrimeArk }^{\circledR} \text { Traveler } & 169 & 166 & 165 & 163 & 160 \mathrm{~b} & 156 \mathrm{a} & 170 & 167 & 164 \mathrm{ab} & 161 \mathrm{~b} & 157 \mathrm{~b} & 154 \mathrm{~b} \\ \text { APF 268T } & 169 & 166 & 164 & 163 & 160 \mathrm{~b} & 153 \mathrm{~b} & 170 & 169 & 166 \mathrm{a} & 164 \mathrm{a} & 161 \mathrm{a} & 159 \mathrm{a} \\ \text { ORUS 4545-1 } & 169 & 166 & 165 & 163 & 159 \mathrm{~b} & 149 \mathrm{c} & 170 & 166 & 163 \mathrm{~b} & 160 \mathrm{~b} & 154 \mathrm{~b} & 150 \mathrm{c} \\ & \text { NS } & \text { NS } & \text { NS } & \text { NS } & & & \text { NS } & \text { NS } & & & \end{array}$

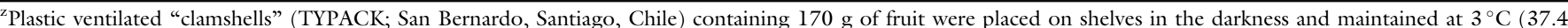

${ }^{\circ} \mathrm{F}$ ) and $65 \%$ relative humidity; $\mathrm{l} \mathrm{g}=0.0353 \mathrm{oz}$.

${ }^{\mathrm{N}} \mathrm{N}$ indicate no significant differences and different letters next to treatment means within each column for raspberries or blackberries indicate significant differences according to Fisher's least significant difference test $(P>0.05)$. 
only production was similar to that in floricane production [regime 1 (Table 4)]. Similar to raspberries, blackberry fruiting was delayed 4 to 6 weeks on primocanes compared with floricanes resulting in overall lower yield in primocane-only management regime. Just as with raspberries, combining production from floricanes and primocanes benefited fruit yields but since blackberries produced even larger biomass and thicker canes than raspberry, access to fruit at harvest and cane training was increasingly challenging during the season. We observed more frequent presence of broad mite and micronutrient deficiency symptoms in high-density plots that had floricanes and primocanes compared with primocane-only plots (data not shown). However, neither pests nor nutrient deficiencies appeared to have any negative impact on marketable yields of blackberries.

POSTHARVEST FRUIT PERFORMANCE IN COLD STORAge. Weight loss was minimal during the first $3 \mathrm{~d}$ in cold storage in both years for all raspberries (Table 5). Among raspberries, 'Vintage' fruit appeared to be more susceptible to weight loss in days 5 to 13 after placement in cold storage in both years and had clamshell weights $3 \%$ to $6 \%$ lower than other cultivars in 2017 and 2\% to 3\% lower than Kokanee in 2018 (Table 5). In 'Vintage' fruit, signs of decay and fungal colonization appeared on day 9 in cold storage, $4 \mathrm{~d}$ earlier than in 'Kwanza' or 'Kokanee' fruit (data not shown).

For blackberries, no significant differences among cultivars were observed in clamshell weight in cold storage until day 9 in 2017 and day 5 in 2018 (Table 5). After those days, 'Prime-Ark ${ }^{\circledR} 45$ ' appeared to retain weight in storage better than 'ORUS 4545-1' and similarly to 'APF 268T' in 2019. At day 13 in storage, only 'ORUS 4545-1' fruit had fungal mycelium growth on fruit (data not shown) suggesting inferior shelf life in storage compared with other tested blackberry cultivars. Similar weight losses in fruit of 'Prime-Ark ${ }^{\circledR} 45$ ' and 'Prime-Ark ${ }^{\circledR}$ Traveler' in cold storage in this study are aligned with findings of Clark and Salgado (2016), who observed that these cultivars did not differ in percent leaked, decayed of soft fruit stored for $7 \mathrm{~d}$ at $5^{\circ} \mathrm{C}$.
Blackberries overall, appeared to have better shelf life than raspberries and slower weight loss, in agreement with differences in respiration rates and ethylene evolution reported previously (Perkins-Veazie and Nonnecke, 1992; Zagory and Kader, 1989).

\section{Conclusions}

These evaluations showed that 'Imara' and 'Kweli' raspberries were among highest yielding cultivars at the two coastal locations and at Oceano, 'Kokanee' yielded similarly. Hanson et al. (2019) evaluated raspberry performance in pots and reported results similar to our field trials: 'Imara' and 'Kweli' were top-yielding cultivars among eight evaluated, but in most years not different from 'Kwanza.' In our study, 'Kwanza' consistently had the largest fruit among all cultivars that were attractive (as observed with shape, color, and firmness) and had better shelf life in cold storage than Vintage. In Oregon, 'Kokanee' produced fruit that were similar or larger than 'Vintage' and yielded greater than 'Heritage' used as standard for raspberry evaluations (Finn et al., 2018).

Raspberry pruning management affects yield and fruit size of the cultivars. Currently, common practice among caneberry growers is to harvest the first season from primocanes for 6-9 months depending upon planting date. Then, plants are pruned at $1 \mathrm{~m}$ height, and floricane fruit can be harvested in 4 to 6 months. The comparisons of pruning regimes in this study confirms this to be the most productive management in California's long growing season.

Among blackberries, 'PrimeArk $^{\circledR} 45^{\prime}$ was consistently the topyielding cultivar at both sites and all seasons, whereas APF 268T yielded similarly to it at Oceano in one season. All blackberry cultivars with exception of ORUS 4545-1 had similarly good shelf life for $13 \mathrm{~d}$ in cold storage. To maximize yields of both blackberries and raspberries, combining production from floricanes and primocanes can be effective; however, such increase in cane density can complicate management of pests, fertigation, and fruit harvest efficiency.

In Arkansas, 'Prime-Ark ${ }^{\circledR} 45$ ' provided significantly greater marketable fruit yields (from floricane and primocane harvests) compared with 'PrimeArk $^{\circledR}$ Traveler' in 3 years of evaluation
(Clark and Salgado, 2016). These findings are in agreement with our study; however, unlike in Arkansas, where individual fruit weights were similar among the two blackberry cultivars, fruit of Prime-Ark ${ }^{\circledR} 45$ in coastal California were always heavier compared with Prime-Ark ${ }^{B}$ Traveler.

Among blackberries in this study 'APF 268T' was the second highest yielding cultivar behind only Prime$\operatorname{Ark}^{\circledR} 45$. Fernandez and Ballington (2010) found that 'APF-series' blackberry selections yielded significantly more and earlier than experimental North Carolina cultivars and floricane production exceeded that of primocane blackberries, similar to this study.

A year-around market for fresh raspberries and blackberries has evolved worldwide over the past 20 years based on a combination of improvement in fruit yield and quality and combining domestic and off-season imports (Tourte et al., 2016). For both raspberries and blackberries, improvements in yield have been accompanied by dramatic improvements in fruit firmness, shape, size, color, and flavor, which have all contributed toward establishing caneberries as mainstream fruit commodities (Clark and Perkins-Veazie, 2011).

Primocane-fruiting cultivars have largely enabled the industry growth. New, widely planted proprietary cultivars have been key to California fresh raspberry and blackberry production and market growth because they had received more attention from proprietary breeding and development programs directed at quality and yield improvement (J. Gomez, personal communication). In the case of blackberries, public cultivars such as those from the University of Arkansas program (Clark and Salgado, 2016) have been instrumental in providing new primocane cultivars to independent growers. California growers currently produce primocane-fruiting fresh raspberries and blackberries every month of the year. This continuous production involves a wide range of components including planting, pruning, trellising, and protected tunnel management.

Reliable fruit yield and quality data for primocane-fruiting caneberries is always somewhat tentative. Yield parameters such as fruit size, fruit number, and timing of fruiting in both 
raspberries and blackberries are markedly affected over multiple seasons by crop phenology. Plants are affected by environment and management at planting and those effects can influence plant growth and yield over multiple successive seasons. The two evaluation sites we used for these studies were both near the central California coast, but varied considerably in production practices (conventional vs. organic), soil types, temperatures, and management approaches, but generally showed similar trends in cultivar performance. The yields and fruit quality in this study clearly demonstrate marked improvements over previously available public cultivars for California growing conditions (Goodhue and Martin, 2018; Tourte et al., 2016), suggesting that these public cultivars approach the yields and vigor of currently planted proprietary cultivars.

Results of these caneberry field trials in California have provided additional information for development of grower guidelines for production of caneberries based on available public cultivars. Dissemination of these updated guidelines is continuing at field days, grower conferences, and via electronic and in-person communications. With increased interest in primocane caneberries, the information generated in this study has provided new resources to guide successful production by small, independent, and direct-sale growers.

\section{Literature cited}

Bolda, M., M. Gaskell, E. Mitcham, and M. Cahn. 2012. Fresh market caneberry production manual. Univ. California Agr. Nat. Resour. Pub. 3525.

Clark, J. and P. Perkins-Veazie. 2011. 'APF-45' primocane-fruiting blackberry. HortScience 46:670-673, doi: 10.21273/ HORTSCI.46.4.670.

Clark, J. and A. Salgado. 2016. 'PrimeArk ${ }^{\circledR}$ Traveler' primocane-fruiting thornless blackberry for the commercial shipping market. HortScience 51:1287-1293, doi: https://doi.org/10.21273/HORTSCI 10753-16.

Fernandez, G. and J. Ballington. 2010. Performance of primocane-fruiting experimental blackberry cultivars in the southern Appalachian Mountains. HortTechnology 20:9961000, doi: 10.21273/HORTSCI.20.6.996.

Finn, C., B. Strik, M. Peterson, B. Yorgey, P. Moore, P. Jones, J. Lee, and R. Martin. 2018. 'Kokanee' primocane-fruiting red raspberry. HortScience 53:380-383, doi: https://doi.org/10.21273/HORTSCI 12691-17.

Gaskell, M., O. Daugovish, and M. Bolda. 2015. Management of primocane fruiting blackberries for extended harvest in a mild winter climate. Acta Hort. 1133:207-210, doi: 10.17660/ActaHortic.2016.1133.31.

Goodhue, R. and L. Martin. 2018. Cane and bush berries, p. 5-7. In: California berries. California agriculture: Dimensions and issues. 20 Apr. 2021. <https://s.giannini. ucop.edu/uploads/giannini_public/5d/ 62/5d624d5a-087a-4cf5-be3c-c322f047 8302 /california_berries.pdf $>$.

Hanson, E., B. Crain, and K. Hanson. 2019. Response of potted red raspberry cultivars to double-cropping under high tunnels. HortScience 54:1972-1975, doi: 10.21273/HORTSCI14435-19.

Hall, H. and R. Funt. 2017. Blackberries and their hybrids. CAB Intl., Boston, MA.
Jenderek, M., B. Ambruzs, G. Holman, D. Skogerboe, E. Staats, M. Turner, and D. Ellis. 2007. Germplasm preservation of vegetatively-propagated crops at the National Center for Genetic Resources Preservation. HortScience 42:962-963, doi: 10.21273/ HORTSCI.42.4.919.

Lawless, L. 2012. Consumer sensory preferences and willingness-to-pay for nutraceutical-rich fruit. Univ. Arkansas, Fayetteville, PhD Diss.

Nile, S. and S. Park. 2014. Edible berries: Bioactive components and their effect on human health. Nutrition 30:134-144, doi: 10.1016/j.nut.2013.04.007.

Perkins-Veazie, P. and G. Nonnecke. 1992. Physiological changes during ripening of raspberry fruit. HortScience 27: 331-333, doi: 10.21273/HORTSCI.27. 4.331 .

Prive, J.-P., J. Sullivan, J. Proctor, and O. Allen. 1993. Climate influences vegetative and reproductive components of primocane-fruiting red raspberry cultivars. J. Amer. Soc. Hort. Sci. 118:393-399, doi: 10.21273/JASHS.118.3.393.

Tourte, L., M. Bolda, and K. Klonsky. 2016. The evolving fresh market berry industry in Santa Cruz and Monterey counties. Calif. Agr. 70:107-115. doi: $10.3733 / \mathrm{ca} .2016 \mathrm{a} 0001$.

University of California, Davis. 2021. SoilWeb. 14 Apr. 2021. < https://casoil resource.lawr.ucdavis.edu/soilweb-apps/>.

Ventura County. 2019. Ventura County Agricultural Commissioner's Crop and Livestock Report 2019. 20 Apr. 2021. <https://cdn.ventura.org/wp-content/ uploads /2020/09/Ag-Comm-2019Crop-Report-.pdf $>$.

Zagory, D. and A. Kader. 1989. Quality maintenance in fresh fruits and vegetables by controlled atmospheres. Amer. Chem. Soc (ACS). Symp. Ser. 405:174-188. 